\title{
Detection of Vascular Dendritic Cells and Extracellular Calcium-Binding Protein S-100 in Foci of Calcification in Human Arteries
}

\author{
Yuri V. Bobryshev and Reginald S. A. Lord \\ Surgical Professiorial Unit, St. Vincents' Hospital, University of New South Wales, Sydney, Australia
}

Received for publication July 28, 1995

\begin{abstract}
A new explanation of why calcification develops in arterial vessels is proposed. Some of recently described $\mathrm{CD} 1 \mathrm{a}^{+} / \mathrm{S}-100^{+}$ vascular dendritic cells have been found to undergo destruction in athero-prone areas of the aorta and in atherosclerotic lesions (Bobryshev and Lord, Arch. Histol. Cytol., 1995). Lysis of these vascular dendritic cells should release their cellular components into the extracellular space, including S-100 which belongs to the family of calcium-binding proteins. In the present study we examined the possible association of vascular dendritic cells with calcification in atherosclerosis and found that vascular dendritic cells were present in early foci of calcification in the arterial intima and in atherosclerotic
\end{abstract}

\begin{abstract}
lesions. This finding suggests the possible involvement of vascular dendritic cells in the process of arterial wall calcification. Vascular dendritic cells and calcifying vascular cells may be related where a subset of vascular dendritic cells represents calcifying vascular cells in the arterial wall. Extracellularly distributed S-100 protein was also found in association with early calcified deposits. The detection of calcium-binding S-100 protein in the extracellular matrix suggests that molecular mechanisms are involved in atherosclerotic calcification, which is quite different from the previously postulated mechanisms involving boneassociated proteins.
\end{abstract}

Key words: Vascular dendritic cells, Dendritic cells intima, Arteries, Arterial calcification, Atherosclerosis, S-100 protein

\section{Introduction}

Recent investigations indicate that atherosclerotic calcification is an active regulated process similar to osteogenesis $[5,9,45]$. In human atherosclerotic plaque, some of the genes expressed for bone-associated calcification-regulating proteins and related proteins have been detected, including phosphorylated glycoprotein osteopontin $[16,17,20,22,31,40]$, matrix Gla protein [40], and a potent osteogenic differentiation factor-protein-2a [9, 45].

The nature of the cells instrumental in atherosclerotic calcification has been intensively studied over the last few years and it is now accepted that smooth muscle cells and macrophages express osteopontin in plaque $[20,22]$. Smooth muscle cells and macrophages are clearly involved in arterial calcification $[20,22]$ but other cells also par-

This research was supported by the Vascular Research Fund, St. Vincent's Hospital, Sydney, Australia.

Correspondence to: Dr. Yuri Bobryshev, Surgical Professiorial Unit, Level 17, O’Brien Building, St. Vincent's Hospital, Darlinghurst, NSW 2010, Australia. ticipate in this process as was recognised in 1993 by Boström and colleagues [9] who named them one year later, calcifying vascular cells [45]. In in vitro experiments calcifying vascular cells assume a stellate shape and produce bone-associated calcification-regulating proteins [9, 45]. Vascular calcifying cells are also responsible for forming calcified nodules in vitro, and they can be modulated by certain mediators found in atherosclerotic arteries [9, 45]. Nevertheless, the nature of these calcifying vascular cells is unknown.

Recently we described the presence of CD1a ${ }^{+} / \mathrm{S}-100^{+}$ vascular dendritic cells in the arterial wall $[6,7]$. Vascular dendritic cells manifest ultrastructural features typical of antigen-presenting dendritic cells and they cluster with lymphocytes [7]. Vascular dendritic cells were detected in atherosclerotic plaques more frequently than in nonatherosclerotic arterial intima [6, 7].

In our previous investigation the destruction of some vascular dendritic cells in the arterial intima was observed [7]. This process should result in the release of their cellular components into the extracellular space including S-100 which belongs to the family of calcium-binding pro- 
teins [19]. In the present study, the possible association of vascular dendritic cells with calcification in the atherosclerosis is examined.

We now report the finding of vascular dendritic cells in foci of calcification in the arterial intima and we suggest the possible involvement of vascular dendritic cells in the calcification process. We also found S-100 protein in association with early calcified deposits in the extracellular matrix. The detection of calcium-binding S-100 protein in extracellular matrix implies the occurrence of a molecular mechanism of atherosclerotic calcification which is different from the mechanisms involving bone-associated proteins postulated by others $[9,16,17,20,22,31,40,45]$.

\section{Materials and Methods}

This investigation conformed with principles of the Declaration of Helsinki [11].

\section{Tissue specimens}

Carotid artery specimens were obtained by endarterectomy and aortic specimens during aortic reconstruction. Twenty carotid arteries and 17 aortic specimens were obtained from adults whose ages ranged from 35 to 65 years. These arterial wall segments were embedded in OCT compound then rapidly frozen in liquid nitrogen and stored at $-70^{\circ} \mathrm{C}$ until they were cryostat sectioned.

\section{Histology}

Sections were cut and stained for histological analysis with Mayer's haematoxylin. The arterial specimens selected for further immunohistochemical investigation included the portions of vessels containing calcified deposits.

\section{Immunohistochemistry}

Sections were cut at $7 \mu \mathrm{m}$ thickness and air dried for $45 \mathrm{~min}$. After eliminating endogenous peroxidase activity by $0.3 \%$ hydrogen peroxide for $5 \mathrm{~min}$, the consecutive tissue sections were preincubated with normal goat serum and then were tested by the $\mathrm{ABC}$ method [21] as previously described [6,7]. In brief, some sections were incubated for 30 min with S-100 (rabbit anti-bovine S-100 protein, DAKO, $1: 600$ dilution) and others with anti-CD1a antibody (DAKO-CD1a, clone NA1/34, 1:50). After washing in tris-phosphate buffered saline (TPBS, $10 \mathrm{~min}$ ), the sections were incubated for 20 min with the appropriate biotin-labelled secondary antibodies (horse antimouse-VECTOR BA-2000, or goat anti-rabbit-VECTOR BA-1000). The sections were then washed in TPBS for 5 min and the avidin-biotin complex (ELITE-ABC, VECTOR PK61000) was added for $30 \mathrm{~min}$. After washing for $10 \mathrm{~min}$ in TPBS, brown staining was produced by $5 \mathrm{~min}$ treatment with 3,3'-diaminobenzidine (DAB). All the incubations were completed at room temperature. For negative controls, the first antibodies were omitted or the sections were treated with the immunoglobulin fraction of non-immune goat serum (VECTOR S-1000) as a substitute for the primary antibody. None of the negative control sections showed positive immune staining. Counterstaining was performed with Mayer's haematoxylin.

\section{Results}

\section{Heterogeneity of calcified deposits in atherosclerotic lesions}

All the specimens of aorta and carotid arteries studied contained calcified deposits but the zones of calcification differed from each other by the dimensions of the deposits which they contained. For convenience of analysis, we classified these zones into three types according to their size and the dimensions of the calcified deposits:

(i) Type I corresponded to zones with a low degree of calcification which spread over $100 \mu \mathrm{m}^{2}$ to $2000 \mu \mathrm{m}^{2}$ and contained calcified deposits, each of which was less than $2 \mu \mathrm{m}$ in diameter. These calcified zones were initial foci for the formation of larger deposits and can be considered to be early calcified deposits. These initial foci of calcification in some area tended to consolidate with each other and thus spread into a larger contiguous area;

(ii) Type II corresponded to zones of moderately advanced calcification which were usually no larger then $3000 \mu \mathrm{m}^{2}$ and which presented with dispersed calcified deposits ranging from $1 \mu \mathrm{m}$ to $10 \mu \mathrm{m}$ in diameter;

(iii) Type III corresponded to zones of completed calcification containing central, dense cores of calcified deposits not less then $30 \mu \mathrm{m}$ in diameter but which were usually much larger and in some instances were even huge. During the cutting of sections, the cores of calcified deposits were often destroyed but they were always surrounded by smaller deposits which varied in size.

Transitional forms between these three types of calcifying areas were observed, confirming our evaluation of their relationship to each other. Although all the specimens studied contained zones of calcification, considerable variations in their number and size were observed in different atherosclerotic lesions of the aorta and carotid arteries. Differences in the distribution of calcified deposits were also noted along every vascular segment. Nevertheless, in all the specimens, foci of calcification tended to be associated with the zone's atheromatous necrotic core or formed large calcified deposits under the fibrous cap. Primary foci of calcification were also regularly seen in the fibrous caps.

\section{Vascular dendritic cells in the arterial wall}

Vascular dendritic cells $\left(\mathrm{S}-100^{+}, \mathrm{CD} \mathrm{a}^{+}\right)$were detected in all samples studied and their distribution was detailed in our previous publications [6,7]. Some of the vascular dendritic cells colocalised with calcified deposits in the arterial wall. The patterns of association of 
vascular dendritic cells with the calcified deposits were similar in carotid arteries and aortic specimens.

\section{Association of vascular dendritic cells with foci of calcified deposits in atherosclerotic lesions}

Immunohistochemical examination of samples of the arterial wall demonstrated the presence of vascular dendritic cells amongst dispersed type I calcified foci and within aggregated calcified areas (Fig. 1). S-100+ vascular dendritic cells in the foci of calcification demonstrated a different appearance from that in non-calcified areas with their cellular contours ranging from well-looking to illdefined (Fig. $1 \mathrm{~A}-\mathrm{C}$ ). In areas of primary calcification, in addition to intact vascular dendritic cells, intensively stained S-100 positive material was detected in the extracellular matrix (Fig. 1C, D) but no staining with S-100 was detected in the extracellular matrix in non-calcified areas. However, some calcified foci did not contain extracellular S-100 staining material, nor did some contain vascular dendritic cells or other cells. In the latter cases, some of
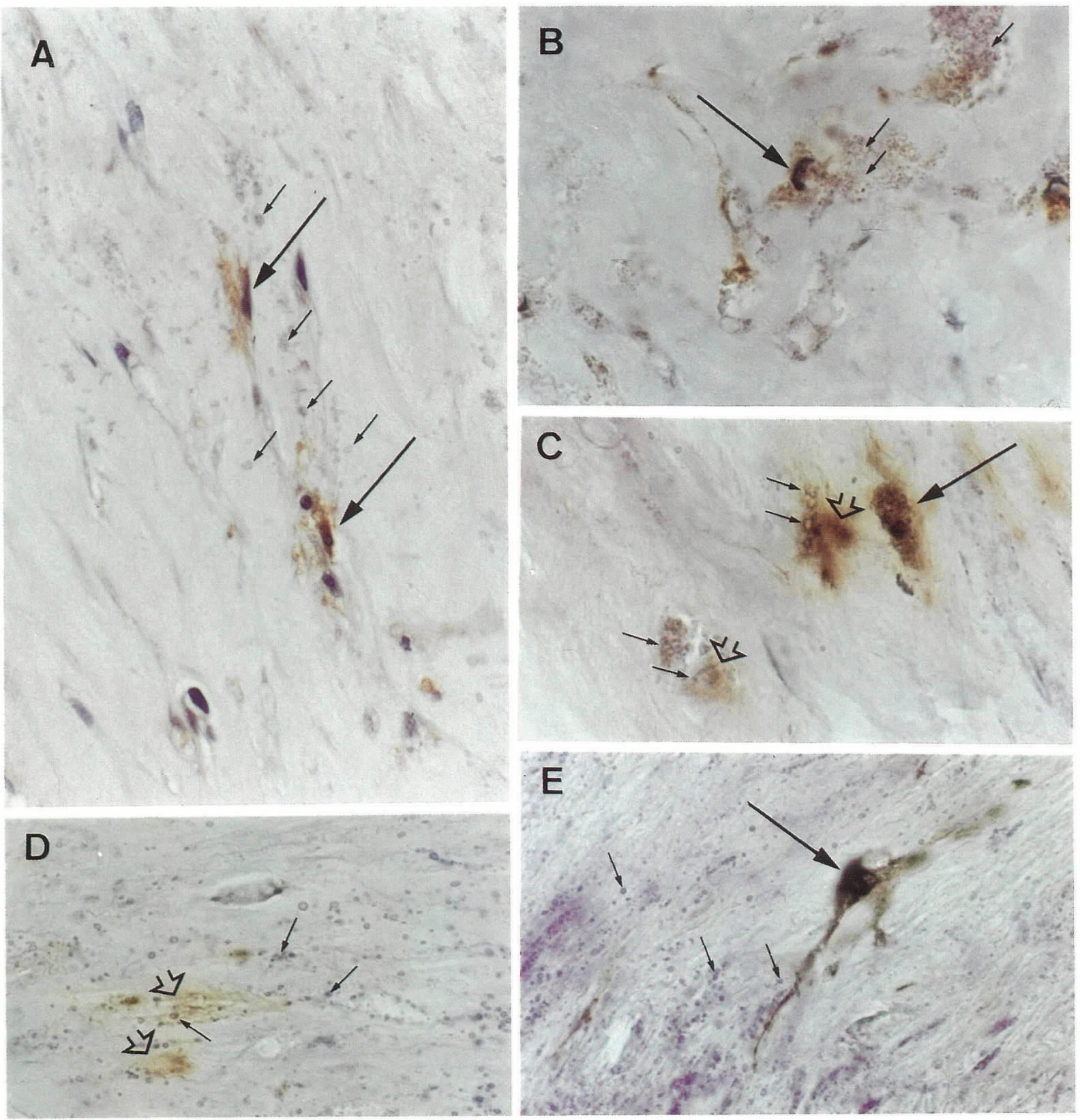

Fig. 1. Vascular dendritic cells and S-100 protein in type I calcified zones. A-C: Note the different appearance of S-100+ positive cells. Vascular dendritic cells are shown by large arrows; some calcified deposits are indicated by small arrows. In panels $\mathbf{C}$ and $\mathbf{D}$ extracellularly located S-100 positive staining material is shown by broken arrows. E: CD1a cells (arrow) in a calcified area. Frozen sections, ABC immunoperoxidase technique, counterstaining with Mayer's haematoxylin. A-D $\times 380, \mathbf{E} \times 480$. 

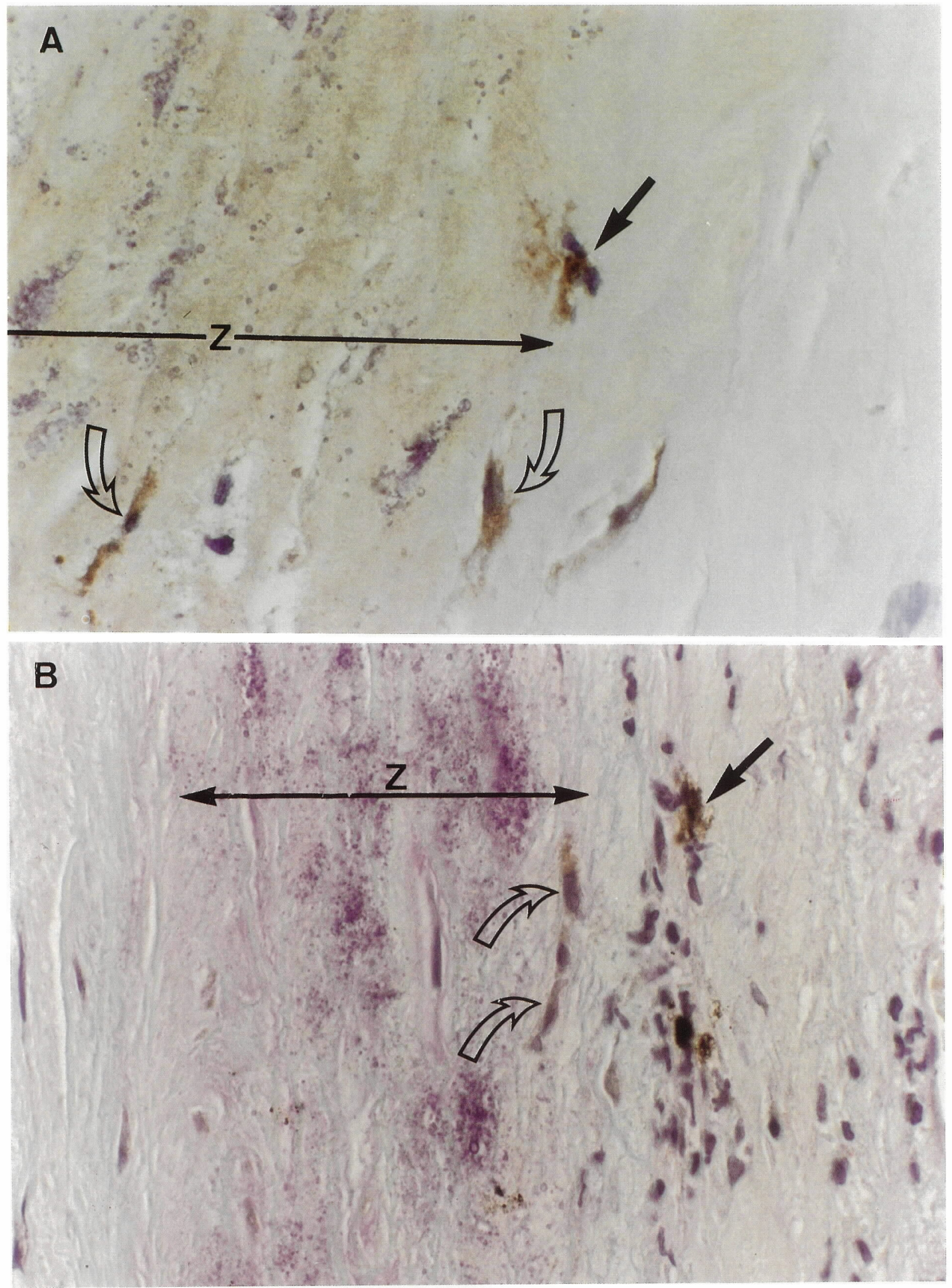

Fig. 2. Vascular dendritic cells located around type I calcified zones containing calcified deposits less than $2 \mu \mathrm{m}$ in diameter each (A, B). Zzone of calcification. Black arrows indicate $\mathrm{S}-100^{+}$vascular dendritic cell with typical stellate appearance; broken arrows show $\mathrm{S}-100^{+}$cells with ill-defined contours. Frozen sections, ABC immunoperoxidase technique, counterstaining with Mayer's haematoxylin. A, B $\times 380$. 
the calcified zones were surrounded by vascular dendritic cells (Fig. 2A, B).

Some zones of type II calcification characterised by clusters of calcified deposits of different sizes contained vascular dendritic cells and sometimes extracellular deposits of S-100 protein (Fig. 3). Some of the S-100 positive cells manifested ill-defined contours suggesting their actual or imminent destruction (Fig. 3).

Large or huge calcified deposits (type III) did not contain $\mathrm{CD} 1 \mathrm{a}^{+} / \mathrm{S}-100^{+}$cells in their centre but sometimes these deposits were surrounded by cells staining positively with anti-CD1a antibody and with S-100 (Fig. 4A, B).

Complicated atherosclerotic plaques contained zones of neovascularization located at some distance from the calcified deposits. The vessels and capillaries formed by neovascularization were located in complicated atherosclerotic plaques, predominantly on the border of the plaque with the media. In these complicated plaques S-100 positive cells were often seen around the vessels formed by neovascularization (Fig. 5). Vascular dendritic cells were located in mosaically distributed groups, mostly close to zones of neovascularization (Fig. 5).

The complicated atherosclerotic plaques contained fibrous caps within which vascular dendritic cells with well developed processes were evenly distributed. Primary foci of calcification or their consolidation were seen in caps, and vascular dendritic cells were detected amongst calcified deposits.

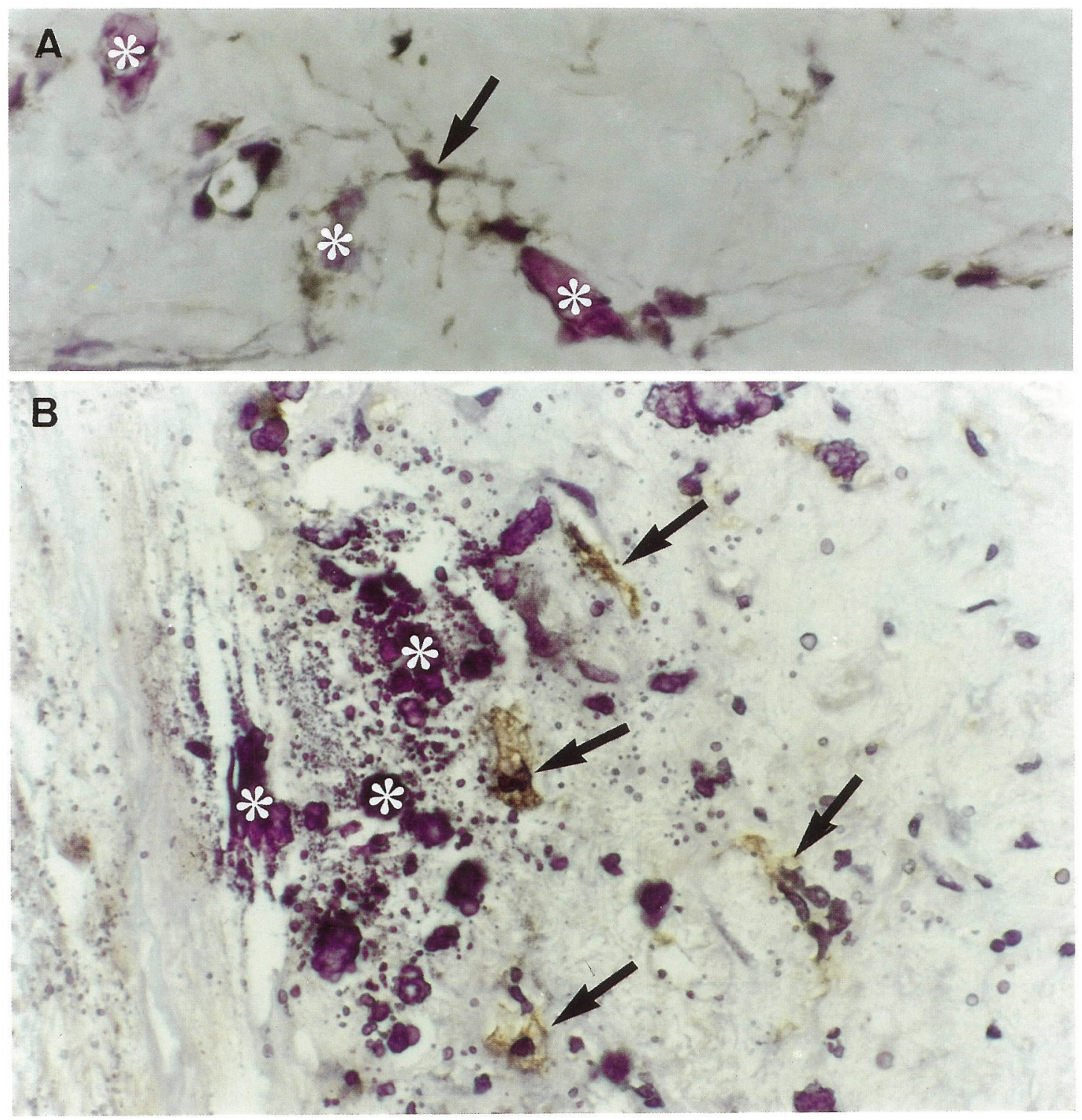

Fig. 3. Association of vascular dendric cells (arrows) with type II calcified zones (A, B). A: CD1a ${ }^{+}$cells. B: S-100 ${ }^{+}$cells showing different appearance. Some calcified deposits are marked by asterisks. Frozen sections, ABC immunoperoxidase technique, counterstaining with Mayer's haematoxylin. A, B $\times 380$. 

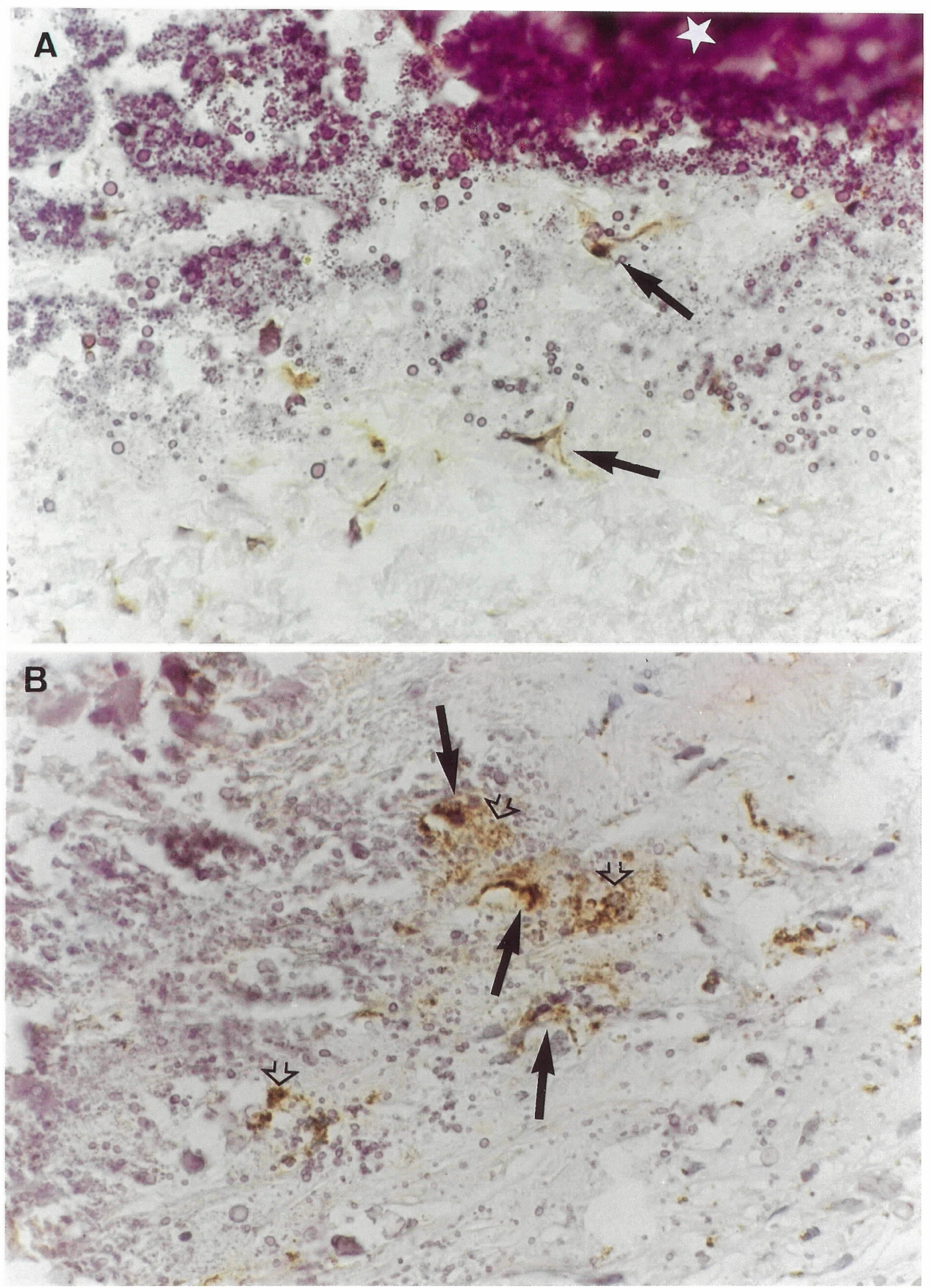

Fig. 4. S-100 positive cells and extracellularly distributed S-100 protein in the border of a calcified zone of type III (A, B). Black arrows indicate vascular dendritic cells. Extracellularly located S-100 protein is indicated by broken arrows. Central core of the calcified zone is marked by star. Frozen sections, ABC immunoperoxidase technique, counterstaining with Mayer's haematoxylin. A, B $\times 380$. 

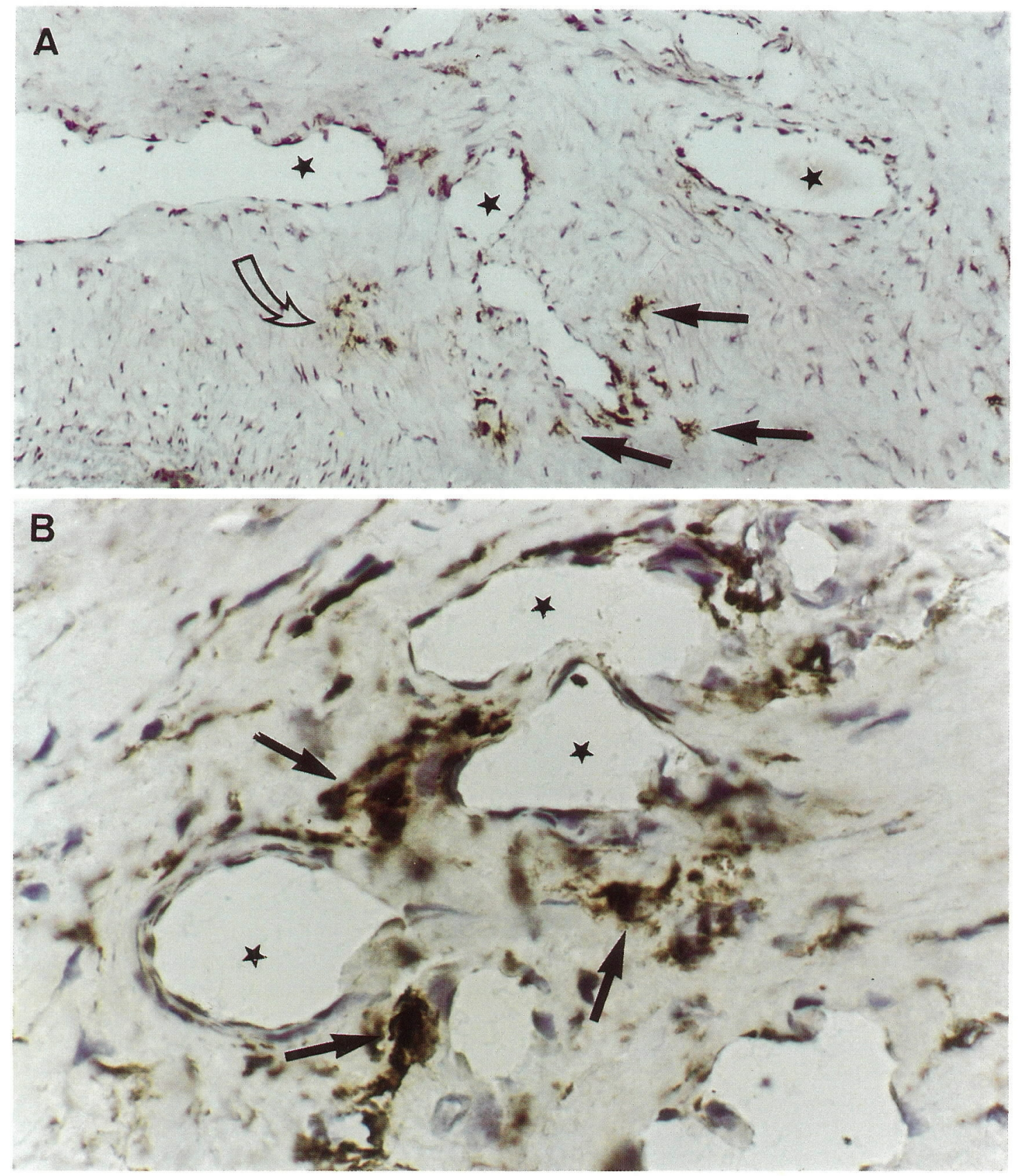

Fig. 5. Location of $\mathrm{CD} 1 \mathrm{a}^{+}$vascular dendritic cells in areas of neovascularization (stars) in complicated atherosclerotic plaques (A, B). Vascular dendritic cells are indicated by black arrows. In panel $\mathbf{A}$, a group of vascular dendritic cells is shown by the broken arrow. Frozen sections, $\mathrm{ABC}$ immunoperoxidase technique, counterstaining with Mayer's haematoxylin. A $\times 120, \quad$ B $\times 480$.

\section{Discussion}

Our previous ultrastructural investigations demonstrated the destruction of some vascular dendritic cells in the arterial wall [7] which should be followed by the release of cellular components into the extracellular space. In the present study, intensive specific staining of the intimal matrix demonstrated both $\mathrm{S}-100^{+}$cells and S$100^{+}$material in and around foci of calcification. Since S-
100 protein belongs to the family of calcium-binding proteins [19], its extracellular accumulation and subsequent impregnation of matrix structures in areas where vascular dendritic cells have been destroyed might initiate local calcification. Based on these observations we consider that S-100 could be responsible for the pathological calcification of arteries either primarily or in combination with other factors including osteopontin, matrix Gla protein and protein-2a. Osteopontin, matrix Gla protein and 
protein $-2 \mathrm{a}$ are bone-associated proteins $[9,16,17,20,22$, $31,40,45]$ and their involvement in atherosclerotic calcification might be through mechanisms similar to those operating in bone. In contrast, S-100 has not been shown to be involved in bone tissue formation but might be involved in or initiate the specific process of calcification occurring in the artery wall. This mechanism might be quite different from those involved in bone tissue formation.

Vascular dendritic cells might also represent a cellular source of calcification. In the present study vascular dendritic cells were often observed in initial calcification foci but the transformation of some well shaped dendritic S-100 positive cells into ill-defined S-100 positive cells was also observed. This process implies a change in the phenotype of vascular dendritic cells and that possibly a subset of modified vascular dendritic cells exists which is responsible for initiating atherosclerotic calcification. This hypothesis requires an examination of the possible relationship between vascular dendritic cells and those cells previously suspected to be active in the pathologic calcification of the arterial wall.

Boström and co-investigators have recently hypothesised that atherosclerotic calcfication is similar to osteogenesis and that this process is regulated by a unique subpopulation of vascular cells which are capable of exhibiting several of the phenotypic features of bone-forming osteoblasts [9, 45]. These "calcifying vascular cells" can be modulated by certain mediators known to exist in atherosclerotic arteries [45]. Calcifying vascular cells constitute a minor population in atherosclerotic lesions but they readily form multicellular nodules which undergo spontaneous calcification in vitro [9, 45]. Calcifying vascular cells exhibit many features characteristic of osteoblasts including the production of alkaline phosphate, collagen type I, osteocalcine, osteonectin, and osteopontin, and they also express bone morphogenic protein-2a in vitro, all of which suggests similarities between bone osteogenesis and arterial calcification [45].

In addition to osteoblasts, these calcifying vascular cells share many similarities with another cell of mesenchymal origin, namely, the microvascular pericyte $[36,38$, 41, 44]. Calcifying vascular cells like pericytes exhibit a stellate shape and stain positively with 3G5 antibody in situ and in vitro [45]. That pericytes or stellate pericytelike cells may play a role in atherogenesis has been suspected for over 100 years since Langhaas [26] described the presence of stellate-shaped cells in the aortic intima, an observation which was subsequently confirmed [1, 33-35, 37]. Boström and colleagues noted that arterial calcification can be mediated by pericyte-like cells and they speculated that calcifying vascular cells may represent one step along the mesenchymal lineage which is intermediate between pericytes and osteoblasts $[9,45]$. This possibility is strongly supported by the observation that calcified nodules formed by artery wall cells in vitro resemble those formed by microvascular pericytes in vitro [9]. Calcified vascular cells resemble pericytes in terms of morphology, growth characteristics, and the staining pattern for actin isoforms and surface gangliosides [12-14, 18, 30]. Brighton et al. suggested that the pericyte may be a possible osteoblast progenitor cell [10]. Calcifying vascular cells also can be referred to as mesenchymal precursor cells or the "pi" cell described previously by Schwartz et al. [39].

In the adult organism, the pericyte is considered to be one of the few cells which retains pluripotentiality [36, 41]. Migration of pericytes from sprouts of neovascularization is one possible explanation for the appearance of calcifying vascular cells in atherosclerotic lesions [45]. However, calcifying vascular cells have been shown to reside in the intima of morphologically normal arteries where there are no capillaries [45]. Recently the circulation of cells originating from bone marrow has been shown to form colony forming units in atherosclerotic intima in vivo and in vitro $[42,43]$, and this finding may explain the appearance of cells responsible for calcification in nonatherosclerotic arterial intima. In our previous study, vascular dendritic cells were detected not only in advanced atherosclerotic lesions with neovascularization but also in early lesions and nonatherosclerotic intima where they were often seen to locate in the subendothelial space close to the endothelium [6, 7] just as pericytes locate in capillaries. Boström et al. [9] have suggested that under the appropriate influence of mediators, pericyte-like cells may express an osteoblast-like phenotype in vivo, similar to that found in vitro.

Although in our present investigation vascular dendritic cells appeared to be involved in atherosclerotic calcification, foci of calcification without vascular dendritic cells and without extracellularly located S-100 were also detected. These foci did not contain other cells which suggests that in atherosclerotic lesions some calcified deposits can form apart from cell-dependent mechanisms. For example, the physicochemical impregnation of extracellular structures by calcium salts has been suggested to be responsible [8]. An alternative explanation may be that some small foci of calcification can remain within a lesion for a long time without progression and during this period the signs of their cell-associated origin is lost.

The present observations suggest that vascular dendritic cells and S-100 protein are associated with atherosclerotic calcification with a subset of modified vascular dendritic cells possibly representing the calcifying vascular cells described by Boström et al. [9]. It is also possible that there are several sources of calcifying vascular cells in the arterial wall just as in bone where colony-forming unit fibroblasts (CFU-f) [3, 4, 29] as well as osteoblasts [23] participate in bone formation. Studies on the nature of the developmental lineages leading to the formation of bone cell types in humans, namely the osteoblast, osteoclast and CFU-f, suggest that osteoclasts may be the progeny of macrophages/monocytes [2, 15, 23] whereas osteoblast and CFU-f arise in some unknown manner 
from local mesenchymal cells and, as such, they do not express the panhaematopoietic cell surface antigen CD34 and fail to respond to haematopoietic growth factors [27, 28]. However, the lack of phenotypically specific markers limits analysis of the origin of dendritic cells [24,25 32] and precludes an analysis of the relation of vascular dendritic cells to bone marrow osteoprogenitor cells.

\section{References}

1. Anitchkow, N. N.: Vessels. Special pathologic anatomy (Russ.), vol. 2, ed. by A. I. Abrikosov, Medgiz, Moskow, 1947, pp. 1-376.

2. Ash, P., Loutit, J. F. and Townsend, K. M. S.: Osteolasts derived from haematopoietic stem cells. Nature (Lond.) 283; 669-670, 1980.

3. Ashton, B. A., Eaglesom, C. C., Bab, I. and Owen, M. E.: Distribution of fibroblastic colony-forming cells in rabbit bone marrow and assay of their osteogenic potential by an in vivo diffusion chamber method. Calcif. Tissue Int. 36; 83-86, 1984.

4. Bab, I., Ashton, B. A., Gazit, D., Marx, G., Williamson, M. C. and Owen, M.E.: Kinetics and differentiation of marrow stromal cells in diffusion chambers in vivo. J. Cell Sci. 84; 139-151, 1986.

5. Berliner, J. A., Navab, M., Fogelman, A. M., Frank, J. S., Demer, L. L., Edwards, P.A., Watson, A. D. and Lusis, A. J.: Atherosclerosis: Basic Mechanisms: Oxidation, Inflammation, and Genetics. Circulation 91; 2488-2496, 1995.

6. Bobryshev, Y. V. and Lord, R.S. A.: S-100 positive cells in human aortic intima and in atherosclerotoc lesions. Cardiovasc. Res. 29; 689-696, 1995.

7. Bobryshev, Y. V. and Lord, R. S. A.: Ultrastructural recognition of cells with dendritic cell morphology in human aortic intima. Contacting interactions of Vascular Dendritic Cells in athero-resistant and atheroprone areas of the normal human aorta. Arch. Histol. Cytol. 58; 307-322, 1995.

8. Bobryshev, Y. V., Lord, R. S. A. and Warren, B. A.: Calcified deposit formation in thickenings of the human aorta. Atherosclerosis 118; 9-21, 1995.

9. Boström K., Watson, K. E., Horn, S., Wortham, C., Herman, I. M. and Demer, L. L.: Bone morphogenic protein expression in human atherosclerotic lesions. J. Clin. Invest. 91; 18001809, 1993.

10. Brighton, C. T., Lorich, D. G., Kupcha, R., Rielly, T. M., Jones, A. R. and Woodbury, R. A.: The pericyte as a possible osteoblast progenitor cell. Clin. Orthop. Relat. Res. 275; 287299, 1992.

11. British Medical Council: Human Experimentation. Code of ethics of the World Medical Association and statement on responsibility in investigations on human subjects. Brit. Med. J. 2; 177-180, 1964.

12. D'Amore, P. A.: Culture and study of pericytes. In "Cell Culture Techniques in Heart and Vessel Research", ed. by H. M. Piper, Springer-Verlag, Berlin, 1990, pp. 299-314.

13. Diaz-Flores, L., Valladares, F., Gutierrez, R. and Varela, H.: The role of pericytes of the adventitial microcirculation in the arterial intimal thickening. Histol. Histopathol. 5; 145-153, 1990.

14. Diaz-Flores, L., Gutierrez, R., Lopez-Alonso, A., Gonzalez, R. and Varela, H.: Pericytes as a supplementary source of osteoblasts in periosteal osteogenesis. Clin. Orthop. Relat. Res. 275; 280-286, 1992.

15. Fischman, D. A. and Hay, E. D.: Origin of osteoclasts from mononuclear leukocytes in regenerating newt limbs. Anat. Rec. 143; 329-339, 1962.
16. Fitzpatrick, L. A., Severson, A., Edwards, W. D. and Ingram, R. T.: Diffuse calcification in human coronary arteries: association of osteopontin with atherosclerosis. J. Clin. Invest. 93; 1597-1604, 1994.

17. Giachelli, C. M., Bae, N., Almeida, M., Denhardt, D. T., Alpers, C. E. and Schwartz, S. M.: Osteopontin is elevated during neointima formation in rat arteries and is a novel component of human atherosclerotic plaques. J. Clin. Invest. 92; 1686-1696, 1993.

18. Herman, I. M. and D'Amore, P. A.: Microvascular pericytes contain muscle and nonmuscle actins. J. Cell Biol. 10; 43-52, 1985.

19. Hilt, D. C. and Kligman, D.: The S-100 protein family: a biochemical and functional overview. In "Novel" Calcium-binding Proteins: Fundamentals and Clinical Implications", ed. by C. W. Heizmann, Springer-Verlag, Berlin, 1991, pp. 65-103.

20. Hirota, S., Imakita, M., Kohri, K., Ito, A., Morii, E., Adachi, S., Kim, H.-M., Kitamura, Y., Yutani, C. and Nomura, S.: Expression of osteopontin messenger RNA by macrophages in atherosclerotic plaques: A possible association with calcification. Am. J. Pathol. 143; 1003-1008, 1993.

21. Hsu, S.-M., Raine, L. and Fanger, H.: Use of avidin-biotinperoxidase complex $(\mathrm{ABC})$ in immunoperoxidase techniques: a comparison between $\mathrm{ABC}$ and unlabeled antibody (PAP) procedures. J. Histochem, Cytochem. 29; 577-580, 1981.

22. Ikeda, T., Shirasawa, T., Esaki, Y., Yoshiki, S. and Hirokawa, $\mathrm{K}$.: Osteopontin mRNA is expressed by smooth muscle-derived foam cells in human atherosclerotoc lesions of the aorta. J. Clin. Invest. 92; 2814-2820, 1993.

23. Jotereau, F. W and Le Douarin, N. M.: The developmental relationship between osteocytes and osteoblasts: a study using the quail-chick nucleus marker in endochondrial ossefication. Dev. Biol. 63; 253-265, 1978.

24. Kamperdijk, E. W. A., Nieuwenhuis, P. and Hoefsmit, E. C. M. (Eds.): Dendritic cells in Fundamental and Clinical Immunology [Advances in Experimental Medicine and Biology. Vol 329]. Plenum Press, New York, 1993.

25. King, P. D. and Katz, D. R.: Mechanisms of dendritic cell function. Immunol. Today 11; 206-211, 1990.

26. Langhaas, T.: Beitrage zur normalen und pathologischen Anatomie der Arterien. Virchows Arch. 36; 187-226, 1866.

27. Long, M. W., Williams, J. L. and Mann, K. G.: Expression of bone-related proteins in the human hematopoietic mcroenvironment. J. Clin. Invest. 86; 1387-1395, 1990.

28. Long, M. W., Robinson, J. A., Ashcraft, E. A. and Mann, K. G.: Regulation of human bone marrow-derived osteoprogenitor cells by osteogenic growth factors. J. Clin. Invest. 95; 881-887, 1995.

29. Luria, E. A., Owen, M. E., Friedenstein, A. J., Morris, J. F. and Kuznetsov, S. A.: Bone formation in organ cultures of bone marrow. Cell Tissue Res. 248; 449-454, 1987.

30. Nayak, R. C., Berman, A. B., George, K. L., Eisenbarth, G. S. and King, G. L.: A monoclonal antibody (3G5)-defined ganglioside antigen is expressed on the cell surface of microvascular pericytes. J. Exp. Med. 167; 1003-1015, 1988.

31. O'Brien, E. R., Garvin, M. R., Stewart, D. K., Hinohara, T., Simpson, J. B., Schwartz, S. M. and Giachelli, C. M.: Osteopontin is synthesized by macrophage, smooth muscle, and endothelial cells in primary and restenotic human coronary atherosclerotic plaques. Arterioscler. Thromb. 14; 1648-1656, 1994.

32. O'Neill, H. C. O.: The lineage relationship of dendritic cells with other haematopoietic cells. Scand. J. Immunol. 39; 513516, 1994.

33. Orekhov, A. N., Andreeva, E. R., Krushinsky, A. V., Novikov, I. D., Tertov, V. V., Nestaiko, G. V., Khashimor, K. A., Repin, 
V.S. and Smirnov, V. N.: Intimal cells and atherosclerosis. Relashionship between the number of intimal cells and major manifestation of atherosclerosis in the human aorta. Am. J. Pathol. 125; 402-414, 1986.

34. Rekhter, M. D., Andreeva, G. K., Mironov, A. A. and Orekhov, A. N.: Three-dimensional cytoarchitecture of normal and atherosclerotic intima of human aorta. Am. J. Pathol. 138; 569-580, 1991.

35. Rekhter, M. D., Andreeva, E. R., Andrainova, I. V., Mironov, A. A. and Orekhov, A. N.: Stellate cells of aortic intima: I. Human and rabbit. Tissue and Cell 24; 689-696, 1992.

36. Rhodin, J.A. G.: Ultrastructure of mammalian venous capillaries, venules, and small collecting veins. J. Ultrastruct. Mol. Struct. Res. 25; 425-500, 1968.

37. Schonfelder, M.: Ortologie und Pathologie der LanghansZellen der Aortenintima des Menschen. Pathol. Microbiol. 33; 129-145, 1969.

38. Schor, A. M., Allen, T. D., Canfield, A. E., Sloan, P. and Schor, S. L.: Pericytes derived from the retinal microvasculature undergo calcification in vitro. J. Cell Sci. 97; 449$461,1990$.

39. Schwartz, S. M., Heimark, R. L. and Majesky, M. W.:
Developmental mechanisms underlying pathology of arteries. Physiol Rev. 70; 1177-1209, 1990.

40. Shanahan, C.M., Cary, N. R. B., Metcalfe, J. C. and Weissberg, P. L.: High expressin of genes for calcificationregulating proteins in human atherosclerotic plaques. J. Clin. Invest. 93; 2393-2402, 1994.

41. Sims, D. E.: Recent advances in pericyte biology-implications for health and disease. Can. J. Cardiol. 7; 431-443, 1991.

42. Soboleva, E. L., Popkova, V., Saburova, O., Tararak, E. and Smirnov, V.: Circulating cells of bone marrow origin and atherosclerosis (Abstr. Xth Int Simp on Atherosclerosis, Montreal, 9-14 October, 1994). Atherosclerosis 109; 348, 1994.

43. Soboleva, E. L., Saburova, O. V., Prokopheva, L. V., Tararak, E. M. and Smirnov, V. N.: Stem cells in blood of patients with primary hypercholesterolemia (Abstr.) Atherosclerosis 115 (Suppl); S60, 1995.

44. Tilton, D. G.: Capillary pericytes: Perspectives and future trends. J. Electron Microsc. 19; 327-344, 1991.

45. Watson, K. E., Boström, K., Ravindranath, R., Lam, T., Norton, B. and Demer, L. L.: TGF- $\beta 1$ and 25-hydroxycholesterol stimulate osteoblast-like vascular cells to calcify. $J$. Clin. Invest. 93; 2106-2113, 1994. 